\title{
MENINGKATKAN PEMAHAMAN PEMBELAJARAN BIOLOGI DENGAN METODE PERCOBAAN PADA POKOK BAHASAN STRUKTUR DAN FUNGSI TUBUH TUMBUHAN DI SMP NEGERI 4 SAMARINDA
}

\author{
Ratna Ningsih* \\ *Guru Mata Pelajaran Biologi di SMP Negeri 4 Samarinda. \\ agunghumaira@gmail.com
}

\begin{abstract}
Abstrak
Telah dilakukan Penelitian Tindakan Kelas yang bertujuan untuk meningkatkan pemahaman siswa terhadap mata pelajaran Biologi pokok bahasan Struktur dan Fungsi Tubuh Tumbuhan melalui metode percobaan. Subyek penelitian adalah siswa kelas VIII-6 SMP Negeri 4 Semester II Tahun Pembelajaran 2018/2019. Penelitian dilaksanakan dalam dua siklus yang masing-masing siklus terdiri atas tiga kali pertemuan. Data penelitian diperoleh melalui pengamatan selama proses pembelajaran berlangsung, pemberian tugas dan tes hasil belajar siswa yang diberikan setiap akhir siklus. Analisis data menggunakan statistik deskriptif dalam bentuk rata-rata dan persentase peningkatan ketuntasan hasil belajar. Hasil analisis menunjukkan adanya peningkatan rata-rata nilai hasil belajar Biologi dan ketuntasan belajar siswa dari siklus I ke siklus II. Hasil belajar pada siklus I diperoleh rata-rata kelas 60,51, sedangkan pada siklus II diperoleh nilai rata-rata kelas 80,92 sehingga persentase peningkatan hasil belajar sebesar 19,5\%. Hasil penelitian ini menunjukkan bahwa penerapan model pembelajaran percobaan dapat meningkatkan pemahaman siswa terhadap materi pelajaran.
\end{abstract}

\section{Kata Kunci: Metode percobaan.}

\section{PENDAHULUAN}

Proses pembelajaran hingga dewasa ini masih memberikan dominasi guru dan tidak memberikan akses bagi peserta didik untuk berkembang secara mandiri melalui penemuan dalam proses berpikirnya.

Kurikulum 2013 menekankan pada penilaian kinerja untuk mengetahui pencapaian kompetensi peserta didik yang meliputi pengetahuan, keterampilan dan sikap, fokus penilaian pendidikan adalah keberhasilan belajar peserta didik untuk mencapai kompetensi yang ditentukan, dalam hal ini guru dapat memperkaya ide dan gagasan guna membantu mengoptimalkan kemampuan berpikir peserta didik.

Salah satu penyebab hal ini adalah bahwa perilaku mengajar guru di sekolah cenderung bersifat belajar pasif dengan menggunakan metode ceramah hampir di sebagian besar aktivitas proses belajar mengajarnya di kelas, (Slimming 1998).
Keterampilan proses yang dapat dikembangkan dalam pembelajaran sains, diantaranya adalah keterampilan mengamati dengan seluruh indera, mengajukan hipotesis, menggunakan alat dan bahan secara benar dengan selalu mempertimbangkan keselamatan kerja, mengajukan pertanyaan, menggolongkan, menafsirkan, mengkomunikasikan hasil temuan secara beragam, menggali dan memilah informasi faktual untuk menguji gagasan atau memecahkan masalah sehari-hari. Metode pembelajaran yang paling sesuai dengan hal ini adalah metode percobaan atau eksperimen.

Permasalahan yang terjadi di sekolah terkait proses pembelajaran sains selama ini adalah guru pada umumnya tidak mementingkan metode pembelajaran melalui percobaan.

Hal ini juga terjadi di SMP N 4 Samarinda. Akibatnya, daya serap siswa terhadap materi pelajaran Biologi belum memuaskan. Ada beberapa siswa yang mendapatkan nilai ujian yang baik, tetapi setelah dianalisis jawaban mereka 
terhadap soal-soal ujian yang diberikan, nampak bahwa mereka hanya mampu pada aspek kognitif saja tetapi rendah pada aspek afektif dan psikomotorik. Sehubungan dengan hal tersebut, penulis selaku guru Biologi, tertarik melakukan penelitian tindakan kelas menerapkan metode percobaan.

Rumusan masalah dalam penelitian ini adalah: "bagaimana meningkatkan pemahaman biologi siswa terhadap struktur dan fungsi tubuh tumbuhan melalui metode percobaan?"

\section{METODE}

Penelitian yang dilaksanakan adalah dengan subjek penelitian siswa SMP 4 Kelas VIII yang berjumlah 32 orang, sedangkan obyek penelitian ini adalah upaya peningkatan pemahaman biologi siswa terhadap materi Struktur dan Fungsi Tubuh. Tumbuhan. Penelitian dilaksanakan selama enam kali tatap muka kelas pada bulan Februari sampai Maret 2018. Penelitian tindakan kelas ini terdiri dari 2 siklus, dan tiap-tiap siklus dilaksanakan dengan 3 kali pertemuan. yang terdiri dari empat langkah yaitu perencanaan, pelaksanaan tindakan, observasi (dilaksanakan bersamaan dengan pelaksanaan tindakan) dan refleksi.

\section{Siklus I}

\section{a. Perencanaan}

Guru merencanakan kegiatan yang akan dilaksanakan. Adapun kegiatan yang dilaksanakan guru pada tahap perencanaan sebagai berikut:

1) Menyampaikan materi pembelajaran yang akan dibahas pada setiap pertemuan.

2) Membuat skenario pembelajaran termasuk prosedur pelaksanaan percobaan dengan menggunakan bahan-bahan di alam untuk setiap pertemuan.

3) Membuat lembar kerja siswa (LKS)

4) Membuat lembar observasi untuk memantau kegiatan guru dan siswa selama proses pembelajaran berlangsung.

5) Membuat alat evaluasi berupa soal tes hasil belajar.

6) Meminta salah seorang teman sejawat untuk berpartisipasi dalam penelitian ini selaku observer yang bertugas melakukan pemantauan terhadap aktivitas guru dan siswa selama proses pembelajaran.

\section{b. Pelaksanaan Tindakan}

Adapun proses pembelajaran yang dilaksanakan pada siklus I sebagai berikut:

\section{Pertemuan 1}

Pada siklus yang pertama terbagi dalam 3 pertemuan dimana pada setiap pertemuan siswa melakukan percobaan, mengisi LKS, membuat laporan percobaan secara kelompok dan menjawab soal latihan.

Kegiatan pembelajaran pada pertemuan pertama sebagai berikut:

(1) Guru membagi siswa ke dalam kelompok-kelompok, setiap kelompok terdiri dari 4 orang.

(2) Siswa dengan bimbingan guru mendiskusikan Struktur dan Fungsi Akar pada Tumbuhan.

(3) Guru memberikan tugas kepada setiap kelompok untuk melakukan percobaan dengan bahan-bahan dan prosedur yang telah disiapkan oleh guru.

(4) Siswa membuat laporan kelompok dari percobaan yang telah dilakukan dan mempresentasikan di depan kelas..

(5) Siswa menjawab 5 soal uraian

Percobaan I

* Tujuan Percobaan:

Untuk mengetahui proses terjadinya osmosis pada akar.

$\rightarrow$ Alat dan Bahan:

Kentang ( 2 buah), cutter, gelas plastik (4 buah), kawat kecil (4 potong), air, gula putih, sendok, gelas ukur, timbangan dan jam.

Cara Kerja Percobaan I 
1. Kupas kulit kentang, kemudian potong masing-masing kentang yang berukuran sedang menjadi dua bagian.

2. Lubangi bagian tengahnya, buat setipis mungkin. Hati-hati jangan sampai robek. Kentang ini berfungsi sebagai membran.

3. Isi lubang pada kentang dengan air gula dengan konsentrasi yang berbeda untuk masing-masing potongan,yaitu : $20 \%$ (20 gram gula dalam $100 \mathrm{~mL}$ air), $40 \%, 60 \%$ dan $80 \%$.

4. Letakkan setiap potongan kentang tersebut di atas gelas yang berisi air dengan setengah bagian kentang terendam oleh air dan biarkan selama 30 menit.

\section{Pertemuan 2}

Kegiatan pembelajaran pada pertemuan kedua adalah sebagai berikut:

(1) Siswa dibagi dalam kelompok setiap kelompok terdiri dari 4 orang, sebagaimana pada pertemuan 1 .

(2) Siswa di bawah bimbingan guru mendiskusikan struktur dan fungsi batang tumbuhan

(3) Guru memberikan tugas kepada siswa untuk melakukan percobaan.

(4) Guru membimbing siswa untuk aktif bekerjasama dalam kelompoknya.

(5) Siswa membuat laporan dari percobaan yang telah dilakukan dan mempresentasikannya.

(6) Mengerjakan soal-soal latihan dalam bentuk uraian sebanyak 5 soal

Percobaan 2

Tujuan Percobaan

Untuk mengetahui perbedaan struktur anatomi batang dikotil dan monokotil.

$\rightarrow$ Alat dan Bahan:

Preparat jadi penampang melintang monokotil dan dikotil, mikroskop, pensil dan kertas.

* Cara Kerja Percobaan 2

1. Letakkan preparat penampang melintang batang dikotil pada meja benda di mikroskop.

2. Awali pengamatan dengan pembesaran lemah, setelah objeknya ditemukan, gunakan pembesaran kuat!
3. Amati dengan seksama bagian epidermis, korteks dan silinder pusat (stele)

4. Cocokkan dengan gambar yang ada dalam buku referensi, kemudian gambar objek tersebut lengkap dengan keterangannya.

5. Lakukan langkah 1 sampai 4 untuk preparat penampang melintang batang monokotil.

6. Bandingkan antara kedua objek tersebut.

7. Tuliskan dalam bentuk tabel perbedaan antara batang dikotil dan monokotil.

\section{Pertemuan 3}

Dalam petemuan 3 waktu petemuan dibagi dua yaitu 40 menit pertama digunakan untuk presentasi laporan kelompok dan diskusi kelas mengenai percobaan 1 dan percobaan 2 kemudian 40 menit digunakan untuk tes

\section{c. Observasi}

Pada tahap observasi, teman sejawat mengamati tindakan yang sedang dilakukan dengan menggunakan catatan lapangan dan analisis dokumen. Catatan lapangan berupa lembar observasi yang digunakan untuk mengidentifikasi aktifitas guru dan siswa dalam proses pembelajaran.

\section{d. Refleksi}

Pada tahap ini, guru bersama observer mendiskusikan kembali hasil tindakan pada siklus I dengan melihat langkah-langkah yang sudah dicapai dan melihat kekurangan-kekurangan dari langkah-langkah/tindakan yang sudah dilakukan, yang nantinya akan diperbaiki pada siklus II.

\section{Siklus II}

Pada siklus II ini, guru kembali membuat perencanaan, melakukan tindakan dalam 3 kali pertemuan dan melakukan evaluasi.

\section{Pertemuan 4}

Kegiatan yang dilakukan adalah sebagai berikut:

(1) Guru membagi siswa ke dalam kelompok-kelompok, setiap kelompok terdiri dari 4 orang. 
(2) Guru memfasilitasi siswa melakukan diskusi kelompok mengenai struktur dan fungsi daun.

(3) Guru memberikan tugas kepada siswa untuk melakukan percobaan seperti dibawah ini.

Percobaan 3

$\leftrightarrow$ Tujuan percobaan

Untuk mengetahui letak stomata pada daun.

Alat dan Bahan

Daun rhoe discolor, mikroskop, gelas obyek, kaca penutup, pipet tetes, air, kertas isap, pensil dan kertas

$\leftrightarrow$ Cara Kerja

1. Ambil sehelai daun Rhoeo discolor, robek bagian permukaan atas dan bawahnya sehingga didapatkan bagian yang tipis. Tandai bagian atas dan bagian bawah supaya tidak tertukar.

2. Letakkan bagian yang tipis tersebut pada gelas objek, kemudian tetesi air dengan menggunakan pipet tetes dan tutup dengan kaca penutup. Jika pada gelas objek banyak terdapat air, maka keringkan air tersebut dengan cara meletakkan kertas isap pada gelas objek tersebut.

3. Letakkan gelas objek pada meja benda. Amati dengan mikroskop pembesaran lemah, stelah objek yang dicari ditemukan ganti dengan pembesaran kuat.

4. Menggambarkan objek yang tampak di mikroskop

\section{Pertemuan 5}

Kegiatan yang dilakukan adalah sebagai berikut:

(1) Guru membagi siswa ke dalam kelompok-kelompok, setiap kelompok terdiri dari 4 orang.

(2) Guru memfasilitasi siswa melakukan diskusi kelompok mengenai struktur dan fungsi bunga.

(3) Guru memberikan tugas kepada siswa untuk melakukan percobaan seperti dibawah ini

Percobaan 4

Tujuan Percobaan:

Untuk mengetahui keanekaragaman bunga.
Alat dan Bahan:

Macam-macam bunga, lup (kaca pembesar), pensil, kertas.

Cara Kerja

1. Setiap kelompok membawa lima jenis bunga yang berbeda.

2. Mengamati semua bunga yang diteliti dengan identifikasi warna mahkota dan kelopak serta jumlah benaang sari dan putik masing masing bunga yang diamati.

\section{e. Observasi}

Pada tahap observasi, teman sejawat mengamati tindakan yang dilakukan dengan menggunakan catatan lapangan dan analisis dokumen. Catatan lapangan berupa lembar observasi yang digunakan untuk mengidentifikasi kelebihan dan kekurangan proses pembelajaran.

\section{f. Refleksi}

Pada tahap ini, guru bersama observer mendiskusikan kembali hasil tindakan pada siklus II dengan melihat hal-hal yang sudah dicapai dan melihat kekuarangan-kekurangan dari langkah-langkah/tindakan yang sudah dilakukan, yang akan diperbaiki pada siklus atau tindakan berikutnya.

\section{HASIL DAN PEMBAHASAN}

\section{Hasil Penelitian}

\section{$>$ Siklus I}

Beberapa permasalahan yang terjadi sebelum diterapkannya metode percobaan yaitu siswa belum memahami konsepkonsep materi, kurangnya minat, motivasi, dan aktifitas siswa dalam proses pembelajaran.

Pada saat dilaksanakan penerapan metode pembelajaran percobaan ini, peneliti mengalami beberapa hambatan atau kesulitan dalam memberi bimbingan praktis pelaksanaan percobaan karena pada umumnya siswa merasa canggung dan ragu-ragu melaksanakan prosedur. Kelas pun menjadi agak ribut karena banyak siswa yang bertanya baik kepada guru maupun kepada sesama siswa. Oleh karena itu penulis meminta bantuan observer yang juga guru biologi untuk 
membantu siswa melakukan percobaan. Akhirnya percobaan pun dapat dilaksanakan tetapi dengan waktu yang sedikit lebih lama dari pada yang direncanakan.

Hasil penilaian observer terhadap proses pembelajaran menunjukkan bahwa proses pembelajaran berlangsung dengan kategori cukup. Aktivitas siswa secara keseluruhan dalam pembelajaran seperti partisipasi, perhatian dan kerjasama dinilai cukup. Nampaknya siswa belum terbiasa dan memahami secara maksimal prosedur pelaksanaan percobaan, tetapi rasa antusiasme siswa terhadap materi pelajaran sangat besar yang terlihat dari rasa ingin tahu mereka pada saat percobaan berlangsung. Namun masih terlihat ada 12 siswa kurang bekerjasama antar sesama anggota kelompok, kurang bersemangat dan kurang berpartisipasi dalam pelaksanaan percobaan. Observer memberi penilaian atas keaktifan siswa sebesar 65.

Hasil belajar pada siklus I yang mencakup aspek kognitif, afektif dan psikomotorik setelah diolah memberikan hasil belajar rata-rata sebesar 69,51 dengan ketuntasan belajar 78,8\%.

Beberapa hambatan yang terjadi selama proses belajar mengajar, antara lain: (i) suasana kelas ribut saat siswa melakukan percobaan, karena siswa belum paham apa yang harus dilakukan dan mereka belum terbiasa belajar dengan melakukan percobaan, (ii) Ada sejumlah siswa yang dominan dalam kegiatan pembelajaran dan sejumlah siswa yang lainnya pasif selama kegiatan pembelajaran berlangsung, (iii) rata-rata hasil belajar sains siswa masih kategori cukup.

Melihat hambatan-hambatan yang terjadi dalam pelaksanaan percoobaan pada siklus pertama tersebut, peneliti dan observer sepakat akan perlunya perbaikan-perbaikan untuk tindakan pada siklus selanjutnya.

Adapun tindakan perbaikan yang harus dilakukan oleh guru/penulis yaitu :
(1) Guru perlu menekankan kembali kepada seluruh siswa agar membaca dengan seksama dan memahami prosedur percobaan sebelum dilaksanakan.

(2) Guru perlu menekankan pentingnya bekerjasama dengan anggota kelompoknya masing-masing sehingga tidak ditemukan lagi siswa yang pasif atau mendominasi tugas yang diberikan.

(3) Guru menekankan kembali kepada siswa untuk lebih serius pada saat diskusi.

(4) Bimbingan guru terhadap siswa harus ditingkatkan dan bimbingan harus diberikan secara merata kepada seluruh siswa.

(5) Memfokuskan perhatian siswa pada saat melakukan percobaan agar tidak terjadi kesalahan prosedur.

\section{$>$ Siklus II}

Hasil observasi pada siklus II cukup meningkat dibandingkan dengan siklus I. Siswa lebih antusias melakukan kegiatan pembelajaran baik dalam diskusi maupun dalam percobaan. Observer mencatat masih ada 7 orang siswa yang kurang dalam partisipasi dan kerjasama kelompok tetapi cukup baik dalam memperhatikan pelaksanaan percobaan. Observer memberi penilaian atas keaktifan siswa sebesar 92, 5 .

Kemampuan guru dalam membimbing dan mengelola kelas dinilai oleh observer baik, guru memberikan bimbingan secara menyeluruh meskipun kurang merata kepada semua kelompok. Guru dinilai tanggap dalam memberikan bantuan jika ada kelompok yang kesulitan dalam melakukan kegiatan percobaan dan mengarahkan siswa untuk membuat kesimpulan dari materi yang telah dipelajari. Pengelolaan kelas juga dinilai baik karena siswa yang biasanya ribut sendiri dengan temannya sudah mengikuti kegiatan pembelajaran sehingga pembelajaran berlangsung dengan lancar.

Pada siklus II ini telah dicapai ketuntasan belajar siswa sebesar 80,92\%, dimana hasil belajar siswa mencapai rata- 
rata kelas 79,92. Berhubung tingkat ketuntasan belajar sudah sangat tinggi dan materi pokok bahasan Struktur dan Fungsi Tubuh Tumbuhan pun sudah selesai maka penelitian tindakan ini dicukupkan sampai siklus II saja.

Berdasarkan data yang diperoleh di atas, penerapan metode percobaan ini telah memberi peningkatan keaktifan siswa sebesar $39,5 \%$, hasil belajar $19,5 \%$ dan persentase ketuntasan belajar meningkat sebesar $21,3 \%$ dari siklus I.

Grafik peningkatan hasil belajar Biologi siswa Kelas VIII SMPN 4 pada pokok bahasan struktur dan fungsi tubuh tumbuhan semester II sebagai berikut :

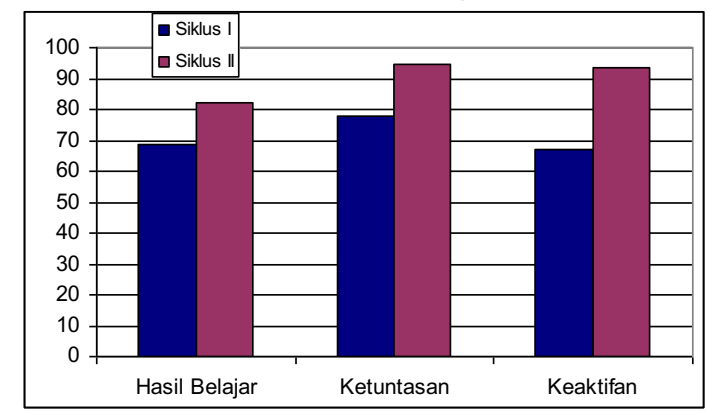

Dari grafik di atas, nampak adanya peningkatan hasil belajar sains setelah diterapkan metode percobaan. Temuan ini mirip dengan temuan Darwis, M. (2008).

\section{A. Pembahasan}

Metode percobaan membuat siswa melakukan dan mengalami proses penemuan ilmu sehingga sangat berkesan dalam benak mereka. Penggunaan bahanbahan di alam sebagai sumber belajar memberikan kesan kedekatan antara siswa dengan obyek yang dipelajarinya, nyata dan tidak abstrak. Faktor-faktor ini merupakan hal memudahkan siswa lebih memahami materi pelajaran.

Adanya peningkatan hasil belajar dan ketuntasan belajar memang dipengaruhi oleh banyak faktor baik faktor ekstrinsik maupun faktor intrinsik. Dalam penelitian ini faktor partisipasi aktif siswa sangat menentukan peningkatan hasil belajar karena dengan banyaknya siswa yang aktif berpartisipasi menyebabkan lebih banyak siswa yang mengalami proses belajar. Hal ini sejalan dengan temuan penelitian dimana pada siklus II partisipasi siswa sangat tinggi, dan hasil belajar dan ketuntasan belajarnya pun sangat tinggi.

Metode belajar melalui percobaan akan mengaktifkan semua panca indera kita. Dengan demikian semua potensi kecerdasan dalam diri siswa difokuskan pada satu hal, yaitu obyek yang sedang dipelajari.

\section{SIMPULAN DAN SARAN}

\section{A. Kesimpulan}

Berdasarkan hasil penelitian tindakan kelas yang telah dilaksanakan dapat disimpulkan bahwa pembelajaran dengan Metode Percobaan mampu meningkatkan hasil belajar siswa Kelas VIII SMP Negeri 4 Samarinda. Penelitian Tindakan Kelas ini telah meningkatkan nilai rata-rata kelas dari 60,51 pada siklus I menjadi 80,92 pada siklus II atau meningkat $19,5 \% \%$.

\section{B. Saran}

Pentingnya metode Percobaan yang dilaksanakan secara optimal, karena selama ini siswa cenderung hanya memahami secara teori. Dengan adanya praktek secara langsung, maka siswa akan lebih mengerti dan memahami materi yang disampaikan sehingga hasil belajarpun akan mengalami peningkatan.

\section{DAFTAR PUSTAKA}

Darwis, M., 2008, Jurnal Pembelajaran Sains, Vol. II No. 2. 146-156

Nurhadi, 2004, Kurikulum 2004 (Pertanyaan dan Jawaban), Jakarta; Grasindo

Nurhadi dan Senduk, A.G., 2004, Pembelajaran Kontekstual dan Penerapannya, Malang; Universitas Negeri Malang

Sukidin, Basrowi dan Susanto., 2002, Manajemen Penelitian Tindakan Kelas, Jakarta; Insan Cita

Sudjana, N., 2000, Penilaian Hasil Proses Belajar Mengajar, Bandung; Remaja Rosda Karya

Wibawa, dkk., 2003, Penelitian Tindakan Kelas, Jakarta; Dirjen Pendidikan Dasar dan Menengah. 